\section{IMAGE UNAVAILABLE FOR COPYRIGHT REASONS}

Carl Lewis (left): the only man to equal Jesse Owens' four Olympic gold medals on the track. for the future of athletic performance."

Some take this further. In Why Things Bite Back: Technology and the Revenge of Unintended Consequences, published earlier this year, Edward Tenner, a former physical science and history editor at Princeton University Press, points out that rising living standards and a suburban environment are "probably the reason for the inability of today's top [baseball] pitchers to match the velocity and skills of the stars of earlier generations".

Supporters of such arguments point out that, at the 1936 Olympic games in Berlin, the US athlete James 'Jesse' Owens, who, along with Carl Lewis, is the only man to win four Olympic gold medals on the track in the same games, clocked 10.3 seconds in the 100-metres sprint, wearing leather shoes and running on a track filled with compressed cinders.

Nevertheless, the contribution of improved - and safer - sporting equipment to world records cannot be underestimated. Impact-absorbing running shoes and smoother, more resilient tracks; aerodynamic javelins and fibreglass poles and rubber foam cushioning for pole vaulters; these have all contributed to improved performance.

Between 1942 and 1960, for example, the world record in the pole vault improved by only $5 \mathrm{~cm}$. But after the introduction of a fibreglass pole in 1963 the record increased by $23 \mathrm{~cm}$ in the first year and has since improved by a further $132 \mathrm{~cm}$.

\section{The unpredictability of limits}

Such advances in equipment fuel the arguments of those who claim that the rate of progression in world records is not about to decline. Edward C. Frederick, for example, a former director of the Nike Sport Research Laboratory in the United States, is also among those who believe that the importance of psychology to human performance is often underrated in predicting future achievements.

Frederick is a former US college athlete who ran the mile in four minutes 17 seconds in 1968, and is now a director of Exeter Research, a sports footwear research consultancy in Exeter, New Hampshire.

He says that scientists should stop "embarrassing themselves" by trying to predict the limits of human performance. "Ever since records have been kept, they have been inexorably broken." Ehsan Masood

\title{
Bannister urges spreading the net
}

London. Sir Roger Bannister, the first man to run a mile in less than four minutes a performance described as breaking "the barrier of barriers" - is no stranger to the limits of athletic performance.

Two years before his historic run, he had been widely tipped to win the 1,500 metres race at the Helsinki Olympics of 1952. Coming into the final stretch of the race, he was, he says, "perfectly positioned with a free run ahead of me. But the finish was just not there."

He finished fourth, and the diagnosis was straightforward. "Muscle problem was what led to my failure," says Bannister, who subsequently became one of Britain's leading neurologists, and stepped down in 1993 as master of Pembroke College at Oxford. "I had trained very little - about half an hour a day, with about five races a year - and the muscles had got used to that. But in Helsinki I was suddenly confronted with three races in three days."

Last year, Bannister stirred up controversy in the British press with remarks to the British Association for the Advancement of Science that black athletes may have certain 'natural anatomical' advantages. These, he suggested, might include a better power-to-weight ratio due to the relative lack of subcutaneous fatty insulating tissue related to living in a warm climate, and even a longer heel bone.

Perhaps inevitably - and despite his own caveats - the statement gave rise to charges of genetic determinism. But Bannister is the first to admit that the ability to break records depends on a complex set of factors, some biological, some psychological and some cultural. "In many run- ning events, physique is not particularly important," he says. "But physiology is - and mental drive is more important than either of these."

In some cases, the physiological differences, even within human races, seem innate. Muscle biopsies from runners have shown that sprinters tend to have a relatively higher percentage of fibres undergoing anaerobic respiration, limiting their need for oxygen over a short burst.

But even innate characteristics are susceptible to external factors, such as training at high altitude. In recent years, runners from Kenya have dominated middle- and long-distance events at the Olympics. The reason may be as much environmental as genetic. "If you live at 8,000 feet, with no school bus service, by the age of seven or eight you are covering large distances every day," he says.

Bannister points out that variation of the human gene pool in terms of athletic performance is fairly widely distributed across all populations. "So far, it has not been proved that members of any one group are so consistently and repeatedly superior as to remove the chance of others beating them," he says. "There was a time when we thought that no-one could beat a Kenyan runner again; but that has not been the case."

One implication, he suggests, is that future improvements in performance will come less from harder training than from selecting athletes from a wider gene pool. "You need an efficient means of selecting those early on whom you think have talent. You then give those with talent expert

\section{IMAGE UNAVAILABLE FOR COPYRIGHT REASONS}

coaching - including a global look at how their lives may develop - as well as a back-up physiology service, able to recognize when they are being overtrained."

Last month, Bannister proposed to the British government that it should set up a special sports scholarships fund, based on funds raised through the new National Lottery, to help do precisely that. While acknowledging that the margin by which records are being broken is diminishing, he confidently predicts that a three-and-ahalf minute mile will be run within the nottoo-distant future.

Science, he suggests, can help to improve performance considerably, not least by helping to ease some of the stress of training and competition; many athletes, he says, fail to reach their full potential because of a lack of the necessary mental skills, including the ability to overcome the pain of extreme effort.

But there will always be factors that science cannot reach. Bannister points out that when Jonathan Edwards - a physicist by training - set a new world record in the triple jump last year, "he did not know how he had done it." 